Impact and Fracture Toughness of Investment Cast, Plasma Sprayed, and Wrought Alloy 718

G. K. Bouse

Howmet Corporation

Operhall Research Center

Whitehall, MI 49461

\title{
INTRODUCTION
}

Impact testing of precision vacuum investment cast nickel base superalloys has received only limited attention in the literature. This is probably because impact is not a primary failure mechanism of the cast components, and there is no general agreement on how to use impact energy terms in design. Lately, structural castings have received increased attention due to their potential for significant cost and weight reductions. castings in this category include turbine cases, stators, diffusers, and bearing housings to name a few. As such, these components may more likely be subjected to impact loading, especially from failed internal rotating components, and projectiles in military applications. Although there are no requirements for impact properties of structural castings, the topic is generating interest, especially when castings are replacing forgings.

Alloy 718 is used to make a variety of structural castings due to its excellent castability, weldability, and overall balance of mechanical properties. These one piece castings are replacing welded assemblies containing both cast and wrought sections, so the impact properties of castings must be compared to their wrought counterparts. The fine grain Microcast-X ${ }^{\circledR}$ process [1] (abbreviated MX) was of interest, because this process has demonstrated significantly improved tensile, fatigue, and rupture properties over the conventionally cast product [2]. The Vacuum Plasma structural Deposition (VPSD ${ }^{\mathrm{Tm}}$ ) process is also a possible contender for containment ring or disk components, and hence is of interest as well.

In the current work, conventional casting and the Microcast- $\mathrm{x}$ process, in addition to wrought and VPSD materials, were investigated to determine their Charpy V-notch (CVN) impact toughness at room temperature. Limited dynamic fracture toughness $\left(K_{\mathrm{Id}}\right)$ data from Charpy specimens will also be presented. 


\section{IITERATURE REVIEW}

Welding researchers have contributed much insight to impact toughness. Generally, a weld simulates a fine, dendritic grain casting. For example, Gordine $[3,4]$ showed that better impact properties could be obtained in Alloy 718 by using lower heat input (comparable to lower superheat), and high solution temperatures, which dissolved most of the Laves phase. In that work, he recorded impact energies of 5-40 ft-lbs $(7-54 \mathrm{~J})$.

Chinese researchers [5] showed that both a decrease in the secondary dendrite arm spacing and the amount of Laves phase contributed to increased toughness in Alloy 718 castings. Both of these effects were promoted by a Mg content in the range of 0.004-0.008\%. These researchers did not indicate what type of impact specimen was used, so it was not possible to draw comparisons to the current work.

For Alloy 718 wrought material, Montano [6], using VIM-ESR-VAR ingots reduced to 6 inch $(15 \mathrm{~cm})$ diameter bars and then double aged, CVN energies in the range of 6.5-15 ft-lbs $(9-20 \mathrm{~J})$ were recorded. This material had a yield strength of the order of $190 \mathrm{ksi}$ (1310 MPa), and a grain size of ASTM 10. Kolts [7] and Onyewuenyi [8] studied forged Alloy 718 used in the oil and gas industries, and for material having a yield strength in the range of $120-150 \mathrm{ksi}(830-1030 \mathrm{MPa})$, CVN energies of $30-80$ $\mathrm{ft}-\mathrm{lbs}(41-108 \mathrm{~J})$ were noted. In these studies it was determined that while the proper yield strength could be achieved by either under- or over-aging, toughness was maximized in the underaged condition.

Fracture toughness testing continues to replace charpy impact testing for many reasons that will not be discussed here. Although no values of $\mathrm{K}_{\mathrm{Id}}$ were found for Alloy 718 in the literature, comparisons to static fracture toughness $\left(\mathrm{K}_{\mathrm{Ic}}\right)$ are possible because the influence of the rate of loading is small for these high strength materials. Mills [9] found that GTA welds achieved $\mathrm{K}_{\mathrm{Ic}}$ values in the range of $55-173 \mathrm{ksi}$ in $(60-190$ MPa $\sqrt{m}$ ), whereas Kennedy et. al. [10] noted that $K_{\mathrm{Ic}}$ values of $100 \mathrm{ksi}$ in (110 MPa $\sqrt{\mathrm{m}}$ ) are routinely achieved for materials used in aerospace applications.

It is probable the renewed interest in the Charpy test, as a way to classify materials by toughness, was prompted by its simplicity and low cost.

\section{MATERIALS, PROCESSES, HEAT TREATMENTS, AND TESTING}

The processing parameters used on the materials in this study are given in Table I. Briefly, the $5 / 8$ inch (16 mm) thick slabs were vacuum investment cast in Howmet production facilities at LaPorte, IN, and Hampton, VA. The VPSD material was processed at the Howmet Technical center in Whitehall, MI. All of the conventionally cast, Microcast-X, and VPSD materials were HIP'd in the Howmet production facilities at Whitehall, MI. These materials were then given several common heat treatments, including a dual temperature age cycle of $1325 \mathrm{~F}(720 \mathrm{C})$ for $8 \mathrm{~h}+$ $1150 \mathrm{~F}(621 \mathrm{C})$ for $8 \mathrm{~h}$ per AMS -5383 specification. Additional processing information on the castings can be obtained in a 
previous publication [2]. The wrought material was procured as a hot finished $3 / 4$ inch $(19 \mathrm{~mm})$ diameter bar, meeting AMS -5662 (excepting final heat treatment). Three grain sizes were produced using three $1 \mathrm{~h}$ solution treatments as shown in Table $I$, followed by a $1750 \mathrm{~F}$ (955C) solution and age cycle. Typical microstructures are shown in Figure 1, and chemical compositions are given in Table II.

TABLE I - PROCESS, MICROSTRUCTURE, MECHANICAL PROPERTIES, AND HEAT TREATMENT INFORMATION FOR ALLOY 718 MATERIALS

\begin{tabular}{|c|c|c|c|c|c|c|c|c|c|c|c|c|}
\hline code & Heat & Process & HIP* & $\begin{array}{l}\text { Thick- } \\
\text { ness }\end{array}$ & $\begin{array}{l}\text { CHARPY } \\
\text { IMPACT } \\
\text { EMERGY } \\
\text { ft-lbs }\end{array}$ & $\begin{array}{l}\text { LATERAL } \\
\text { EXPANSION } \\
\text { mits }\end{array}$ & $\begin{array}{c}\text { GRAIN } \\
\text { DiMMETER } \\
\text { mm }\end{array}$ & $\begin{array}{l}\text { UTs } \\
\mathbf{k s i}\end{array}$ & $\begin{array}{l}\text { ys } \\
\text { ksi }\end{array}$ & $x \in 1$ & xan & Heat Treatment \\
\hline$M X-S T D$ & $\begin{array}{l}\hat{A} \\
\mathbf{C} \\
\hat{A}\end{array}$ & $\begin{array}{l}M X(M P+5 F) \\
M X(M P+2 O F) \\
M X(M P+2 O F) \\
M X(M P+35 F)\end{array}$ & $2050 \mathrm{~F} / 4 \mathrm{~h}$ & $5 / 8 \mathrm{in}$. & $\begin{array}{c}15 \\
10 \\
8 \\
16\end{array}$ & $\begin{array}{l}10 \\
6 \\
6 \\
10\end{array}$ & $\begin{array}{l}0.08 \\
0.07 \\
0.07 \\
0.08\end{array}$ & $\begin{array}{l}173.9 \\
177.6 \\
172.9 \\
167.8\end{array}$ & $\begin{array}{l}145.1 \\
154.1 \\
149.9 \\
138.2\end{array}$ & $\begin{array}{l}17.4 \\
12.0 \\
10.8 \\
18.7\end{array}$ & $\begin{array}{l}24.8 \\
18.1 \\
16.2 \\
25.8\end{array}$ & AMS-5383 \\
\hline$m x-v I$ & $\begin{array}{l}\mathrm{c} \\
\mathrm{c}\end{array}$ & $M x(M P+20 F)$ & $2125 \mathrm{~F} / 3 \mathrm{~h}$ & $5 / 8 \mathrm{in}$. & $\begin{array}{l}11 \\
11\end{array}$ & $\begin{array}{l}4 \\
4\end{array}$ & $\begin{array}{l}0.13 \\
0.12\end{array}$ & $\begin{array}{l}171.0 \\
171.0\end{array}$ & $\begin{array}{l}151.1 \\
151.1\end{array}$ & $\begin{array}{l}11.6 \\
11.6\end{array}$ & $\begin{array}{l}18.5 \\
18.5\end{array}$ & AMS- 5383 \\
\hline$m x-v I I$ & $\begin{array}{l}\text { c } \\
\text { c }\end{array}$ & $M X(M P+2 O F)$ & $2175 F / 4 \mathrm{~h}$ & $5 / 8 \mathrm{in.}$ & $\begin{array}{l}22 \\
21\end{array}$ & $\begin{array}{l}16 \\
14\end{array}$ & $\begin{array}{l}0.46 \\
0.40\end{array}$ & $\begin{array}{l}157.6 \\
157.6\end{array}$ & $\begin{array}{l}135.3 \\
135.3\end{array}$ & $\begin{array}{l}19.7 \\
19.7\end{array}$ & $\begin{array}{l}26.0 \\
26.0\end{array}$ & AMS -5383 \\
\hline$M x-v I I I$ & $\begin{array}{l}D \\
D \\
B \\
B \\
C \\
C\end{array}$ & $M X(M P+2 O F)$ & $2050 / / 4 \mathrm{~h}$ & $5 / 8 \mathrm{in.}$ & $\begin{array}{l}15 \\
14 \\
22 \\
19 \\
18 \\
19\end{array}$ & $\begin{array}{l}14 \\
14 \\
20 \\
20 \\
24 \\
14\end{array}$ & $\begin{array}{l}0.26 \\
0.20 \\
0.29 \\
0.24 \\
0.19 \\
0.19\end{array}$ & $\begin{array}{l}161.6 \\
161.6 \\
163.6 \\
163.6 \\
168.3 \\
168.3\end{array}$ & $\begin{array}{l}137.3 \\
137.3 \\
141.1 \\
141.1 \\
151.5 \\
151.6\end{array}$ & $\begin{array}{l}20.7 \\
20.7 \\
15.3 \\
15.3 \\
16.7 \\
16.7\end{array}$ & $\begin{array}{l}21.9 \\
21.9 \\
22.5 \\
22.5 \\
26.1 \\
26.1\end{array}$ & $\begin{array}{l}\text { Proprietary } \\
\text { Homogenization } \\
\text { Cycle (\#) } \\
+ \text { AMS-5383 }\end{array}$ \\
\hline MX-VIIIIA & $\begin{array}{l}D \\
D\end{array}$ & $M X(M P+20 F)$ & $2050 \mathrm{~F} / 4 \mathrm{~h}$ & $5 / 8 \mathrm{in}$. & $\begin{array}{l}15 \\
14\end{array}$ & $\begin{array}{l}14 \\
12\end{array}$ & $\begin{array}{l}0.32 \\
0.23\end{array}$ & $\begin{array}{l}159.4 \\
159.4\end{array}$ & $\begin{array}{l}134.8 \\
134.8\end{array}$ & $\begin{array}{l}16.8 \\
16.8\end{array}$ & $\begin{array}{l}18.7 \\
18.7\end{array}$ & $\begin{array}{l}\text { cycle }(\# \#)+ \\
2000 \mathrm{~F} / \mathrm{h}+ \\
1600 \mathrm{~h} / \mathrm{HWh}+ \\
1750 \mathrm{~F} / \mathrm{h}+ \\
\text { AMS-5383 Age }\end{array}$ \\
\hline$M X-I X$ & $\begin{array}{l}D \\
D \\
B \\
B \\
C \\
C\end{array}$ & $M X(M P+2 O F)$ & $2125 \mathrm{~F} / 3 \mathrm{~h}$ & $5 / 8 \mathrm{in}$. & $\begin{array}{l}17 \\
16 \\
24 \\
27 \\
18 \\
27\end{array}$ & $\begin{array}{l}14 \\
16 \\
22 \\
22 \\
18 \\
24\end{array}$ & $\begin{array}{l}0.36 \\
0.26 \\
0.39 \\
0.36 \\
0.12 \\
0.33\end{array}$ & $\begin{array}{l}155.9 \\
155.9 \\
155.6 \\
155.6 \\
162.9 \\
162.9\end{array}$ & $\begin{array}{c}130.3 \\
130.3 \\
131.8 \\
131.8 \\
140 \\
140\end{array}$ & $\begin{array}{l}22.9 \\
22.9 \\
19.8 \\
19.8 \\
26.0 \\
26.0\end{array}$ & $\begin{array}{l}24.8 \\
24.8 \\
26.1 \\
26.1 \\
29.9 \\
29.9\end{array}$ & $\begin{array}{l}2100 F / 4 \mathrm{~h}+ \\
\text { AMS-5383 }\end{array}$ \\
\hline$M X-I \times A$ & $\begin{array}{l}D \\
D\end{array}$ & $M x(M P+2 O F)$ & $2125 \mathrm{~F} / 3 \mathrm{~h}$ & $5 / 8 \mathrm{in.}$ & $\begin{array}{l}17 \\
14\end{array}$ & $\begin{array}{l}14 \\
12\end{array}$ & $\begin{array}{l}0.37 \\
0.26\end{array}$ & $\begin{array}{l}157.0 \\
157.0\end{array}$ & $\begin{array}{l}136.1 \\
136.1\end{array}$ & $\begin{array}{l}14.6 \\
14.6\end{array}$ & $\begin{array}{l}17.1 \\
17.1\end{array}$ & $\begin{array}{l}2100 \mathrm{~F} / 4 \mathrm{~h}+ \\
2000 \mathrm{~F} / \mathrm{h}+ \\
1600 \mathrm{~h} / 10 \mathrm{~h}+ \\
1750 \mathrm{~F} / \mathrm{hh}+ \\
\text { AMS-5383 Age }\end{array}$ \\
\hline$C C+H I P$ & $\begin{array}{l}\hat{A} \\
\hat{A} \\
\hat{A} \\
\hat{A} \\
\hat{A}\end{array}$ & $\begin{array}{l}\text { Conv. Cast } \\
\begin{array}{c}\text { (MP }+300 \mathrm{~F}) \\
+\mathrm{HIP}\end{array}\end{array}$ & $2050 \mathrm{~F} / 4 \mathrm{~h}$ & $5 / 8$ in. & $\begin{array}{l}32 \\
32 \\
42 \\
47 \\
47 \\
23\end{array}$ & $\begin{array}{l}24 \\
26 \\
30 \\
32 \\
30 \\
16\end{array}$ & $\sim 6.0$ & $\begin{array}{l}135.5 \\
135.5 \\
135.5 \\
135.5 \\
135.5 \\
135.5\end{array}$ & $\begin{array}{l}120.2 \\
120.2 \\
120.2 \\
120.2 \\
120.2 \\
120.2\end{array}$ & $\begin{array}{l}18.8 \\
18.8 \\
18.8 \\
18.8 \\
18.8 \\
18.8\end{array}$ & $\begin{array}{l}27.9 \\
27.9 \\
27.9 \\
27.9 \\
27.9 \\
27.9\end{array}$ & AMS-5383 \\
\hline VPSD & $\begin{array}{l}\mathrm{E} \\
\mathrm{E}\end{array}$ & $\begin{array}{l}\text { PLASMA } \\
\text { SPRAYED }\end{array}$ & $2125 \mathrm{~F} / 3 \mathrm{~h}$ & $1 \mathrm{in.}$ & $\begin{array}{l}21 \\
22\end{array}$ & $\begin{array}{l}12 \\
16\end{array}$ & $\begin{array}{l}0.02 \\
0.02\end{array}$ & $\begin{array}{l}206.1 \\
206.1\end{array}$ & $\begin{array}{l}163.7 \\
163.7\end{array}$ & $\begin{array}{l}22.0 \\
22.0\end{array}$ & $\begin{array}{l}43.9 \\
43.9\end{array}$ & AMS-5383 \\
\hline \multirow[t]{3}{*}{ WROUGHT } & \multirow{3}{*}{$\begin{array}{l}F \\
F \\
F \\
F \\
F \\
F\end{array}$} & \multirow[t]{3}{*}{ HROUGHT } & (2050F Sol'n) & \multirow[t]{3}{*}{$\begin{array}{c}\text { 3/4 in. } \\
\text { Dia. }\end{array}$} & $\begin{array}{l}38 \\
37\end{array}$ & $\begin{array}{l}28 \\
24\end{array}$ & $\begin{array}{l}0.18 \\
0.18\end{array}$ & $\begin{array}{l}178.8 \\
178.8\end{array}$ & $\begin{array}{l}143.4 \\
143.4\end{array}$ & $\begin{array}{l}34.1 \\
34.1\end{array}$ & $\begin{array}{l}37.3 \\
37.3\end{array}$ & \multirow[t]{3}{*}{$\begin{array}{l}1750 F / 1 \mathrm{~h}+ \\
\text { AMS-5383 Age }\end{array}$} \\
\hline & & & (1900F sol'n) & & $\begin{array}{l}34 \\
33 \\
\end{array}$ & $\begin{array}{l}20 \\
20 \\
\end{array}$ & $\begin{array}{l}0.07 \\
0.07\end{array}$ & $\begin{array}{l}188.0 \\
188.0 \\
\end{array}$ & $\begin{array}{l}146.7 \\
146.7 \\
\end{array}$ & $\begin{array}{l}32.7 \\
32.7 \\
\end{array}$ & $\begin{array}{l}46.1 \\
46.1 \\
\end{array}$ & \\
\hline & & & (1750F sol'n) & & $\begin{array}{l}13 \\
12\end{array}$ & $\begin{array}{l}6 \\
8\end{array}$ & $\begin{array}{l}0.01 \\
0.01\end{array}$ & $\begin{array}{l}210.0 \\
210.0\end{array}$ & $\begin{array}{l}174.3 \\
174.3\end{array}$ & $\begin{array}{l}23.9 \\
23.9\end{array}$ & $\begin{array}{l}36.6 \\
36.6\end{array}$ & \\
\hline
\end{tabular}




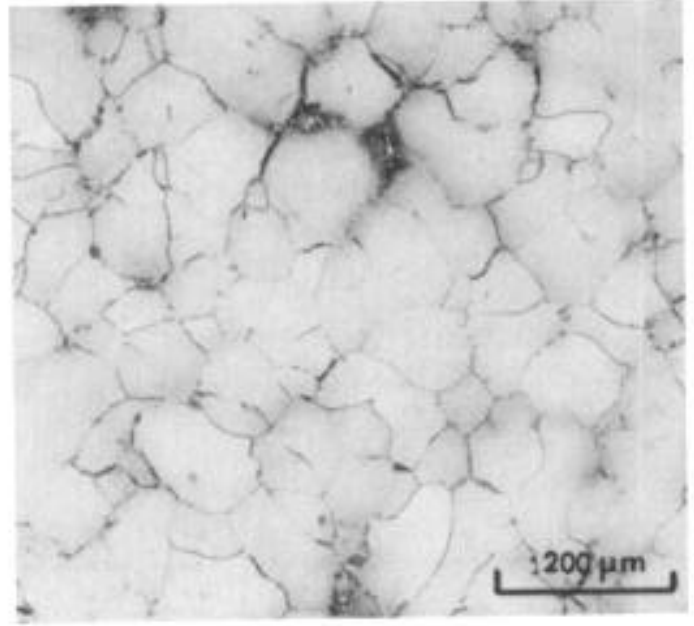

Microcast- $X^{*}$ material, standard heat treatment Grain Size ASTM 3-4.

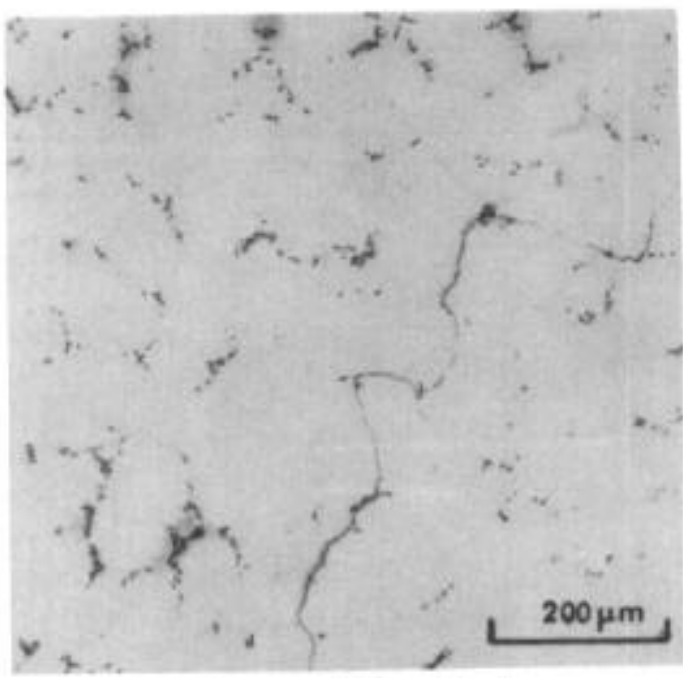

Conventionally cast + HIP material

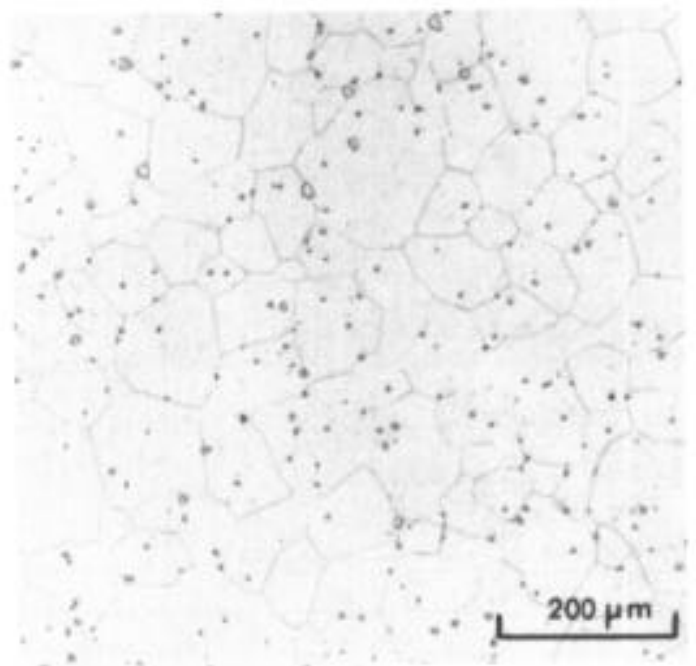

Wrought material, grain size $0.07 \mathrm{~mm}$ diameter, ASTM 4-5

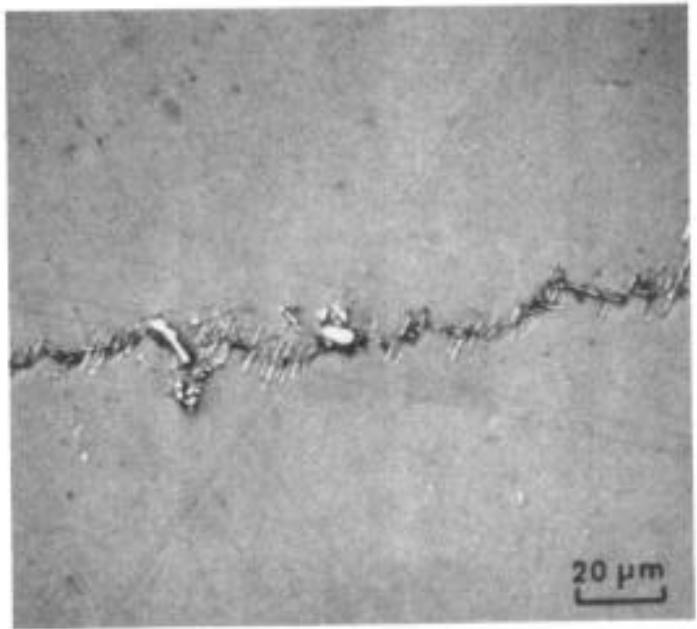

Serrated grain boundaries produced in MX-VIIIA and MX-IXA modifications.

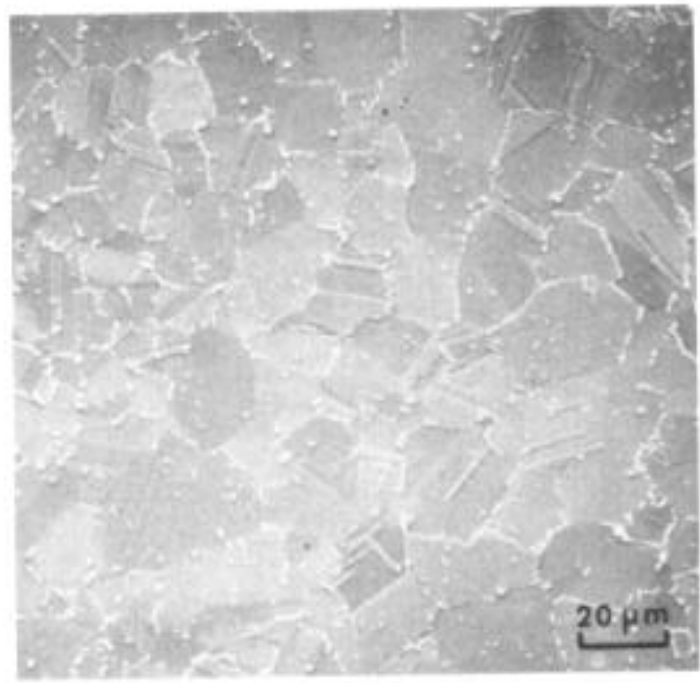

VPSD" plasma sprayed material.

Figure 1. Microstructures of the different forms of Alloy 718 studied. 
Thermal cycles VI and VII were applied to the Microcast-X, to simulate typical treatments used to process aerospace materials. Thermal cycles VIII and IX were applied to the Microcast-X material for the purpose of homogenization of Laves phase. This essentially was accomplished with the parameters used, but at the expense of some grain growth. Heat treatments VIIIA and IXA included a technique to produce a serrated grain boundary [11], to promote a more difficult crack path and increase impact energies.

All Charpy V-notch specimens were machined and impact tested per AS'IM E23 at Westmoreland Mechanical Testing \& Research. The Charpy specimen was $10 \mathrm{~mm}$ square by $55 \mathrm{~mm}$ long with the $45^{\circ}$ notch, $2 \mathrm{~mm}$ deep. Several Charpy specimens were also precracked and $K_{\mathrm{Id}}$ tested on an instrumented impact machine per the proposed ASTM E24 guidelines.

The tensile tests were conducted according to the requirements of ASTM E8. Extensometers were used to measure the $0.2 \%$ offset yield strength at a strain controlled rate of $0.005 / \mathrm{minute}$, after which a crosshead speed of 0.05 inch/minute $(1.27 \mathrm{~mm} / \mathrm{min}$. was maintained. All tensile testing was conducted on specimens having a diameter of 0.25 inches $(6.4 \mathrm{~mm})$ with an $1 / d$ ratio in the gauge of 5. All testing was performed at approximately $70 \mathrm{~F}$ (21C). Test results are given in Table $I$.

\section{RESULTS AND DISCUSSIONS}

\section{Charpy V-Notch Impact Tests}

The CVN energy was first reviewed with respect to grain size, as shown in Figure 2. The VPSD and wrought materials are related in one group, the Microcast-X materials (including the heat treat modifications) are in another group, while the conventionally cast + HIP materials are in a third group. It was surprising to find the Microcast-X material had low CVN energy, since this material has such exceptional tensile, fatigue, and rupture properties [2]. The fractures of the fine grained equiaxed materials (MX, VPSD, \& wrought), examined with the SEM, were all generally mixed mode (intergranular \& transgranular). All of the fracture surfaces had a "dimpled rupture" appearance, indicating good cohesion at grain boundaries.

Typical fracture surfaces of the conventionally cast materials are shown in Figure 3. It is interesting to note the specimen with the lowest toughness had the dendrites parallel to the notch, while the specimen with the highest toughness had the dendrites at about a 45 degree angle. The presence and orienta-

TABLE II - COMPOSITIONS OF ALLOY 718 MATERIALS (WEIGHT PERCENT)

$\% \mathrm{Cb}$

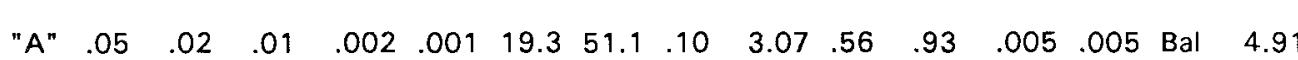

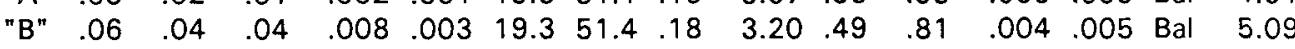

$\begin{array}{llllllllllllllll}{ }^{\circ} \mathrm{C} " & .05 & .04 & .06 & .008 & .003 & 19.6 & 50.9 & .21 & 3.16 & .52 & .88 & .006 & .006 & \mathrm{Bal} & 5.36\end{array}$

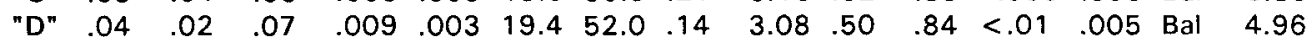

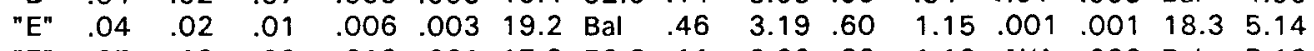

$\begin{array}{lllllllllllllllll} & \text { "F" } & .05 & .18 & .22 & .012 & .001 & 17.9 & 53.6 & .11 & 3.00 & .63 & 1.12 & \mathrm{~N} / \mathrm{A} & .003 & \mathrm{Bal} & 5.12\end{array}$ 


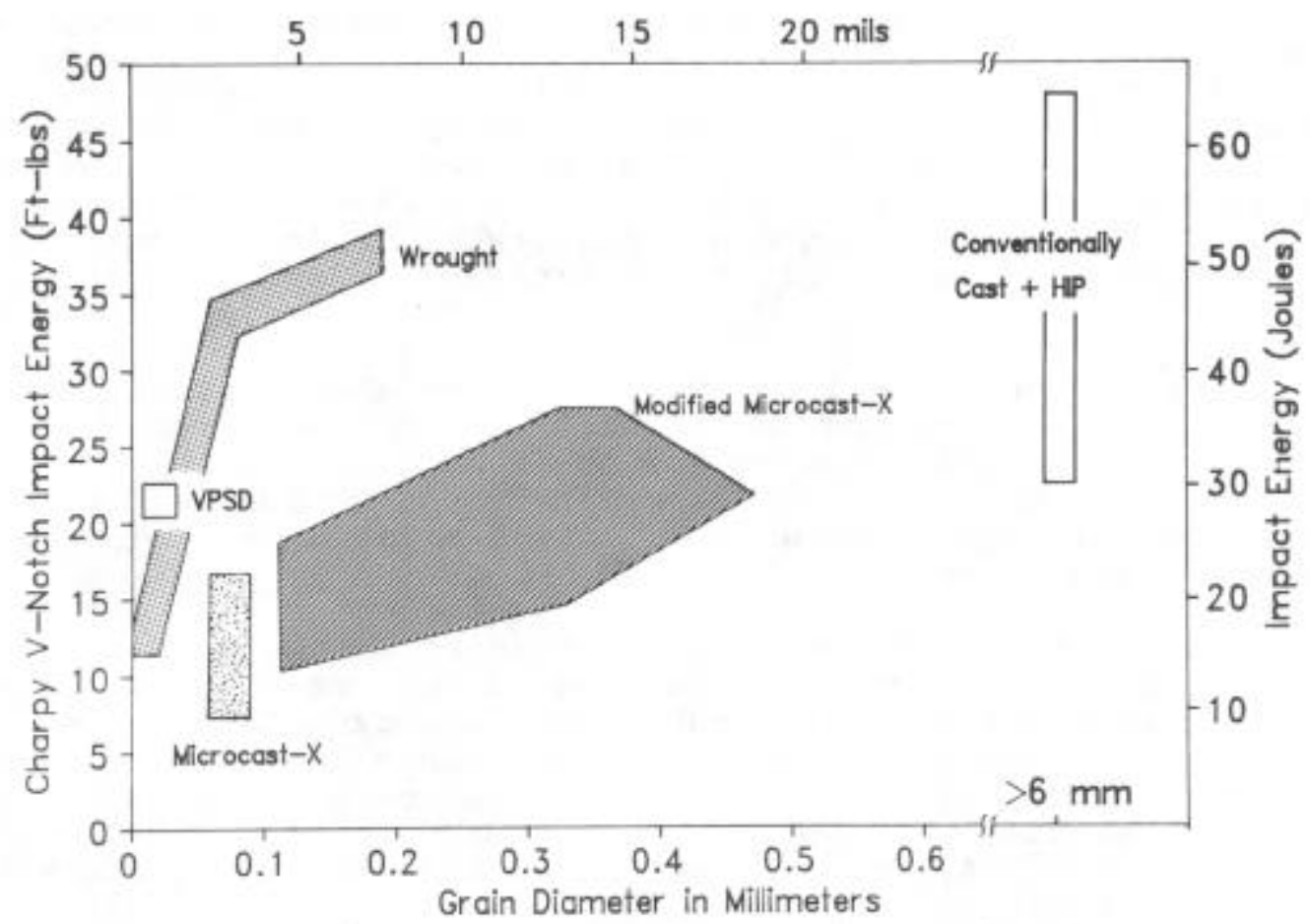

Figure 2. Charpy impact energy at room temperature versus grain diameter for Alloy 718 materials.

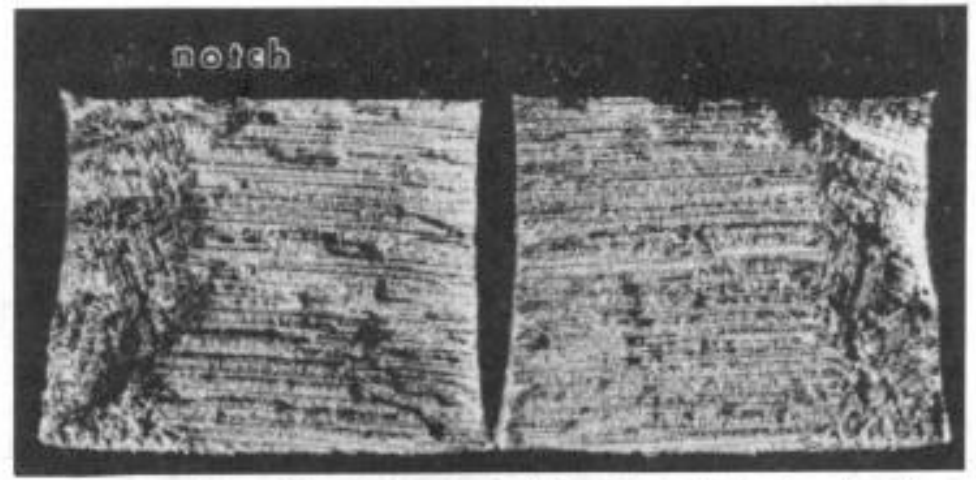

Conventionally Cast + HIP Alloy $718,23 \mathrm{ft}$-lbs (31 J)

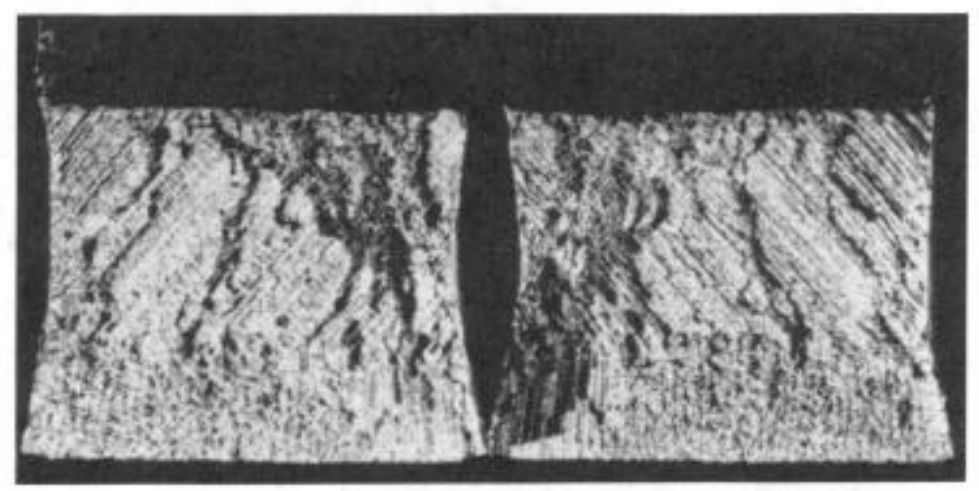

Conventionally Cast + HIP Alloy 718, $47 \mathrm{ft}$-lbs (64 J)

Figure 3. Fracture surfaces of conventionally cast + HIP Charpy bars. Maximum Charpy V-Notch energy was achieved when the dendrites were $45^{\circ}$ to the notch. 
tion of the dendrites undoubtedly influences both the scatter of the test results and the high level of toughness as the crack must maneuver around and through the dendrites. All of the Microcast-X materials (including the modifications) had less scatter than the conventionally cast + HIP material.

When the impact energy is compared to the lateral expansion, Figure 4, the different forms of material become almost homologous. As in steels, the lateral expansions of the Charpy specimens for these $\mathrm{Ni}$ base alloys is also shown to be proportional to the CVN energy.

The impact energy was compared to the yield strength, Figure 5 . Again the material forms are separated. Generally, the CVN energy decreases as the yield strength increases, with the wrought and VPSD materials in one band, and the cast materials in another "band". Ford and Arthey [12] had a similar conclusion when examining the impact properties of MM002 conventional castings and wrought N155. They also noted the impact energy increases as the tensile elongation increases, which with the exception of the conventional cast + HIP Alloy 718, was also observed here.

In many of these tests, the Microcast-X (and modifications thereof) have a grain size and yield strength similar to the wrought material, yet they have lower CVN energy. Since fracture was partially intergranular, part of the reason for lower CVN energy of the castings must be related to the grain boundaries. The only difference between the MX, and wrought and VPSD material, would be the presence of some Laves or delta phase in the grain boundaries of the cast material. Interestingly, a difference between MX and conventional castings is that Laves phase in MX material forms at the grain boundaries, whereas with conventional castings some of the

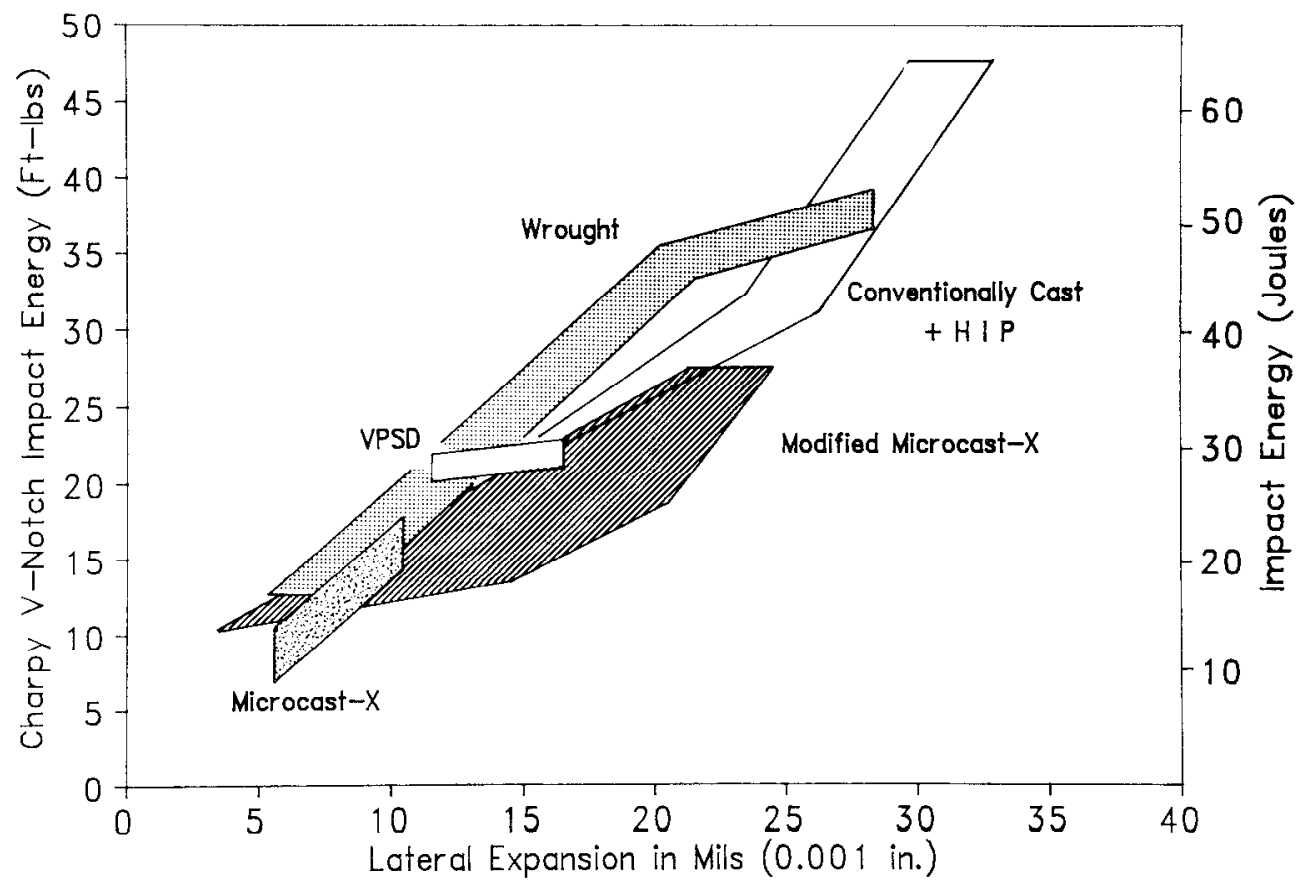

Figure 4. Charpy impact energy at room temperature versus lateral expansion for Alloy 718 materials. 
Laves is in the interdendritic regions, with the remainder in the grain boundaries. Almost all of the MX materials with the homogenization heat treatments had higher CVN energy than the standard MX material, and this was probably because of a reduced amount of Laves phase. Similar conclusions were also reached by Chen et. al. [5] and Mills [9].

The amount of Laves phase in standard Microcast-X material was measured to be between 2.5-3 areal percent using quantitative metallographic techniques. Using a ranking from 1 to 10 ( 1 being essentially no Laves, and 10 being the maximum amount of Laves observed in segregated castings), standard Microcast- $X$ material was as high as "5". The homogenized materials were generally in the range of "2-3" with an occasional "3-4", so the amount of Laves remaining in the MX modified materials is estimated to be less than about $1.5 \%$.

The VPSD material underwent a rapid solidification, suppressing the formation of Laves phase, which is probably the rcason for its excellent impact properties. However, the VPSD material visually contained more delta phase than the wrought material, so for impact resistance, Laves is more deleterious than delta.

Regarding the serrated grain boundaries, more work must be done. The serrations probably occurred on less than $10 \%$ of the grain boundaries, and apparently did not provide the anticipated restrictions to crack propagation. It is not clear why the specimens with the serrated boundaries (MX-VIIIA and MX-IXA) actually had CVN energies towards the lower end of the scatter band. Since the serrated boundaries had delta phase growing perpendicular to the grain boundaries, whereas the VPSD material had delta phase parallel to the grain boundaries, it is probable the morphology and amount of delta phase is important.

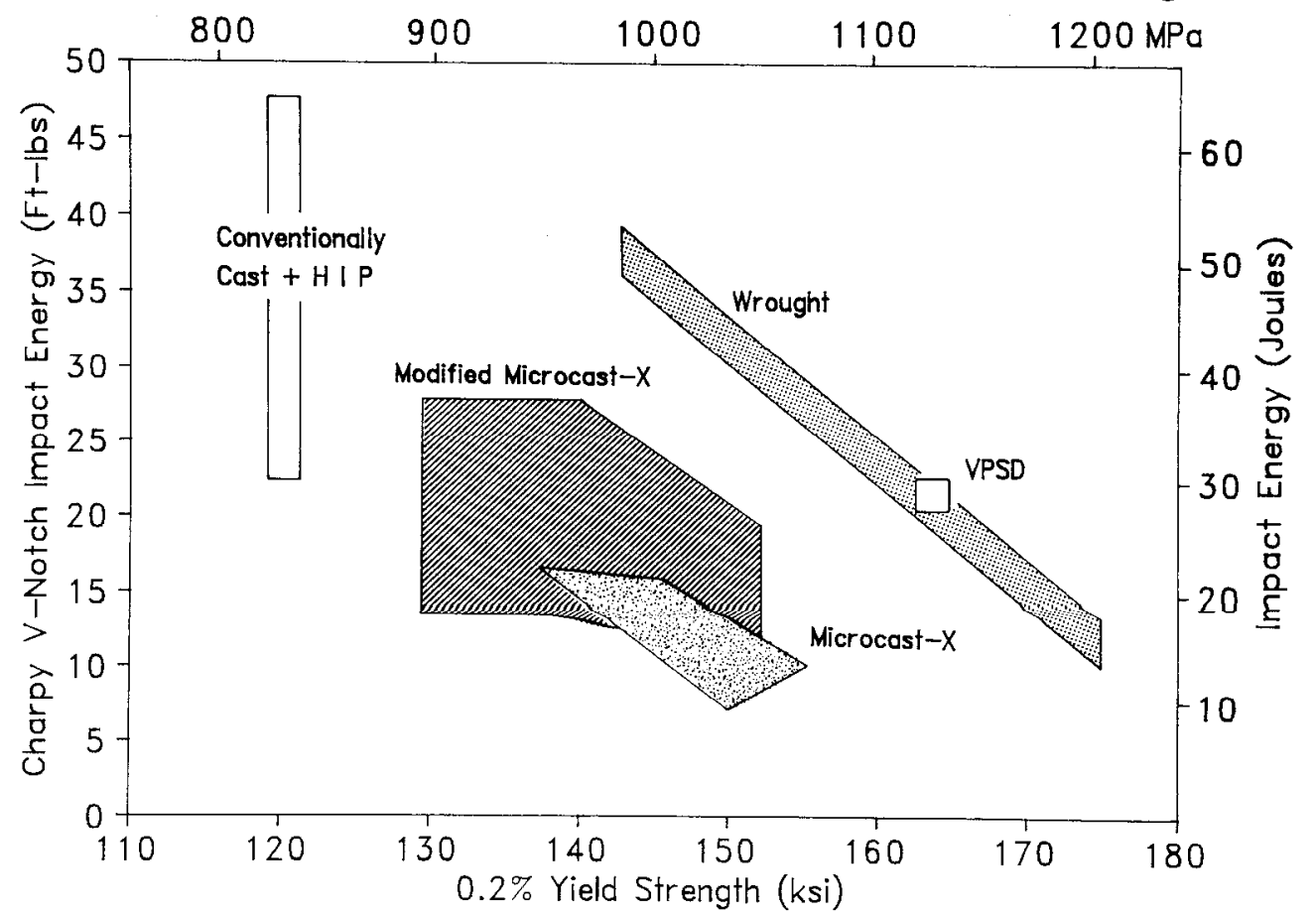

Figure 5. Charpy impact energy at room temperature versus yield strength for Alloy 718 materials. 


\section{Dynamic Impact Fracture Toughness}

A limited amount of $\mathrm{K}_{\mathrm{Id}}$ testing was undertaken to determine the relative difference between the cast and wrought forms of Alloy 718. This data is shown in Table III. Only one test on the wrought material (grain size $0.07 \mathrm{~mm}$ ) produced a valid $\mathrm{K}_{\mathrm{Id}}$ value; the $K_{I d}$ values of the other materials were conditional primarily because general yielding occurred before fracture, and the precrack, expressed as a/w, was too long $(0.58<a / w<0.62$ instead of $0.45<a / w<0.55)$. Due to the absence of other valid data, comparisons will be made, based on the average conditional $\mathrm{K}_{\mathrm{Id}}$ values.

The data shows the investment cast material has between $83-93 \%$ of the conditional dynamic fracture toughness when compared to the AMS-5662 wrought material. Thus, because the tensile yield strength is accounted for in $K_{I d}$, the Microcast-X material compares very favorably to the wrought material.

\section{TABLE III - DYNAMIC FRACTURE TOUGHNESS TESTS OF ALLOY 718 MATERIALS (CHARPY SIZED SPECIMENS) \$}

\begin{tabular}{|c|c|c|c|c|c|}
\hline $\begin{array}{l}\text { MATERIAL } \\
\text { FORM + } \\
\end{array}$ & $\begin{array}{l}K_{\text {ld }} \\
\text { VALUE* } \\
\end{array}$ & $\begin{array}{l}\mathrm{K}_{\mathrm{ld}} \\
\text { CONDITIONAL } \\
\text { VALUES } \\
\end{array}$ & $\begin{array}{l}\text { REASONS FOR } \\
\text { CONDITIONAL } \\
\text { VALUES @ } \\
\end{array}$ & $\begin{array}{l}\text { AVERAGE } \\
\text { CONDITIONAL } \\
\text { KE }_{\text {VALUE }}\end{array}$ & $\begin{array}{l}\text { PERCENT OF } \\
\text { WROUGHT }\end{array}$ \\
\hline Microcast- $X$ & $\begin{array}{l}-- \\
-- \\
--\end{array}$ & $\begin{array}{c}99(109) \\
101(110) \\
104(114) \\
118(130)\end{array}$ & $\begin{array}{l}1,2 \\
1,2,3 \\
1,2 \\
1,2\end{array}$ & $106(116)$ & $88 \%$ \\
\hline$\overline{M X-V I}$ & -- & $\begin{array}{c}97(107) \\
129(142)\end{array}$ & $\begin{array}{l}1,2,3,4 \\
1,2,4\end{array}$ & $113(124)$ & $93 \%$ \\
\hline MX-VII & - & $\begin{array}{c}97(107) \\
104(114)\end{array}$ & $\begin{array}{l}1,2 \\
1\end{array}$ & $101(110)$ & $83 \%$ \\
\hline $\begin{array}{l}\text { Conv. Cast } \\
+ \text { HIP }\end{array}$ & -- & $\begin{array}{c}84(92) \\
130(143)\end{array}$ & $\begin{array}{l}1,3 \\
1,2,4\end{array}$ & $107(118)$ & $88 \%$ \\
\hline $\begin{array}{l}\text { Wrought } \\
(0.07 \mathrm{~mm} \text { gs) }\end{array}$ & $91(100)$ & $121(133)$ & 1 & $121(133)$ & $100 \%$ \\
\hline
\end{tabular}

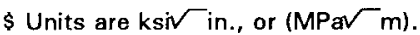

+ See Table I for codes.

${ }^{*} K_{\mathrm{b}}$ values meet the proposed criteria of ASTM E24.

@ Reasons for Conditional $K_{k d}$ Values:

1 = general yielding occurred before fracture

2 = precrack too long

$3=$ differences between A2, A3, \& A4 precrack lengths too great

$4=\mathrm{A} 1$ or A5 precrack lengths less than $.8 \times$ average precrack length

\section{CONCLUSIONS}

1. Maximum Charpy (CVN) impact energy was achieved in the conventionally cast + IIIP material, and was promoted by the dendritic structure, especially when the dendrites were at a 45 degree angle to the notch.

2. Wrought and VPSD plasma sprayed materials had very similar CVN properties, and maximum CVN energy was promoted by coarse grain size. 
3. The fine grain Microcast-X process, which produces the best tensile, fatigue, and rupture properties when compared to any cast + HIP Alloy 718 , resulted in lower CVN energy. This loss in CVN energy was attributed to Laves phase in the grain boundaries.

4. The homogenized Microcast-X material (heat treatments VIII and IX) with less Laves phase, had intermediate CVN energy.

5. Heat treatments VIIIA and IXA, used to promote a serrated grain boundary, resulted in structures with only about $10 \%$ serrated boundaries, and did not markedly improve CVN energy.

6. The Microcast-X castings, and conventionally cast $+\mathrm{HIP}$ castings had between $83-93 \%$ of the conditional dynamic fracture toughness $\left(\mathrm{K}_{\mathrm{Id}}\right)$ when compared to the wrought material.

\section{ACRNOWLEDGEMENTS}

The author would like to acknowledge several Howmet personnel: L. DePatto and J.Lane for discussions regarding heat treatment; $\mathrm{B}$. Foreman for discussions on impact testing of castings; K. Bowen who provided the VPSD material; D.Bakos for metallography;

B.P.Gu for SEM fractography; F.Norris and W.Freeman for reviewing earlier versions of this paper.

\section{REFERENCES}

1. J.R.Brinegar, K.R.Chamberlain, J.J.Vresics and W.J.DePue, U.S. Patent "A Method of Forming a Fine-Grained Equiaxed Casting", No. 4,832,112, May 23, 1989.

2. G.K.Bouse \& M.R.Behrendt, "Mechanical Properties of Microcast-X Alloy 718 Fine Grain Investment Castings", Superalloy 718, Ed. by E.Loria, TMS (1989), p319.

3. J.Gordine, "Welding of Inconel 718", Welding Research Supplement, November 1970, p531s.

4. J.Gordine, "Some Problems in Welding Inconel 718", Welding Research Supplement, November 1971, p480s.

5. G.Chen, Q.Zhu, D.Wang, X.Xie, and J.Radavich, "Effects of $\mathrm{Mg}$ on $\mathrm{Nb}$ Segregation and Impact Toughness in Cast Alloy 718", Superalloy 718, Ed. by E.Loria, TMS (1989), p545.

6. J.W.Montano, "Mechanical Property and SCC Evaluation of VIMESR-VAR ... Inconel 718 Bar Material", NASA Technical Paper No. 2634, Sept. 1986.

7. J.Kolts, "Alloy 718 For the Oil and Gas Industry", Superalloy 718, Ed. by E.Loria, TMS (1989), p329.

8. O.A. Onyewuenyi, "Alloy 718 Alloy Optimization for Applications in oil and Gas Production", Superalloy 718, Ed. by E.Loria, TMS (1989), p345.

9. W.J.Mills, "Effect of Heat Treatment on the Tensile and Fracture Toughness Behavior of Alloy 718 Weldments", Welding Research Supplement, August 1984, p237s.

10. R.L.Kennedy, R.M.Davis, and F.P.Vaccaro, "An Evaluation of Spray Formed Alloy 718", Superalloy 718, Ed. by E.Loria, TMS (1989), p97.

11. A.K.Koul and G.H.Gessinger, "On the Mechanism of Serrated Grain Boundary Formation in Ni-Based Superalloys", Acta Met. v31 (1983), p1061.

12. D.A.Ford and R.P.Arthey, "Development of SC Alloys for Specific Engine Applications", Superalloys 1984, Ed. by M.Gell et.al., p115. 